\title{
The Influences of High Performance Work System on Trust in Management, and Personal Safety Orientation of Surabaya Fire Fighters
}

\author{
Zainal Arief \\ Doctoral StudentOf Economics, \\ University of 17 August 1945 Surabaya \\ Ida Aju Brahmasari \\ Lecturer of Faculty of Economic, \\ University of 17 August 1945 Surabaya \\ Anis Eliyana \\ Lecturer of Faculty of Economic and Bussiness, \\ Airlangga University Surabaya
}

\begin{abstract}
The aims of this study to verify and analyzes on the influences of High Performance Work Systems, Trust in Management and Personal Safety Orientation of Surabaya Fire Fighters. Research population comprise 240 civil servants from firefighting division has characteristic of 3 UPTD's (Regional Technical Implementer Unit) that are UPTD I (Central Surabaya), UPTD II (North Surabaya), UPTD III (East Surabaya), Sample size which meeting the criteria as $\mathbf{2 0 0}$ civil servants from firefighting division. This study designed in survey research form, because through questionnaire instruments such as statements to be responded as primary data collecting outcome. Data collection result which stated valid and reliable, then processed to make analysis by employed Structural Equation Modeling (SEM). The result of the study showed that High Performance Work System influence insignificant on Personal Safety Orientation, High Performance Work System have significant influence on Trust in Management, Trust in Management have significant Personal Safety Orientation.
\end{abstract}

Keywords: High Performance Work System, Personal Safety Orientation, Trust in Management.

\section{INTRODUCTION}

This study will choose Surabaya Fire Fighters as research objects. Due to fire fighter as an one profession which has high risk level and sometimes his life as the bet under his work activities and from the interview upshot that during the last three years since 2015, 2016 and 2017 the work accidental is increase on Surabaya fire fighters to 30,38 and 48 times incidences.

Work safety as a crucial variable in the organization.

\section{HPWS ( Heigh Performance Work System)}

\section{LITERATURE REVIEW}

HPWS is a system of Human Resources Practices designed to improving the skills, commitment and productivity of the employees (Datta et al., 2005) Combs et al., (2006) added that the crucial steps undertaken by Human Resources identified as High Performance Work Systems are such as training, performance-oriented pay, focus specifically on employee recruitment and selection, information sharing as well as fl exible working hours . High Performance Work Systems which are combined with training and development on skills owned by employees are 
also believed to be able to increase the value of employees which is one of the most important assets in an organization (Harel and Tzafrir, 1999; Wang et al., 2009)

\section{Trust In Management}

In Zacharatos et al., (2005) study, trust in management can be come forth when the company able to presenting capable practices that make their employee trust on the company such as provide properly treatment that be performed by the organization to their employees through facilities grant suitable with existing standards, then the company also give workload appropriate with employee's job description and standard operational procedure that had determined before. Trust in the concept of strategic human resource management (HRM) is associated with the commitment that employees have that can be identified as antecedents that can improve organizational performance (Nichols et al., 2009).

\section{Personal Safety Orientation}

In study of Neal et al, (2000) researcher identify dimensions that afore mentioned by Zacharatos et al. (2005) be tested in his experiment as a part of safety performance variable in study of Neal et al, (2000) as reflection of safety performance model applied by Noel and Griffin (1997) also as base of the job performance theory expressed by Borman and Motowidlo (1993) and Campbell et al., (1993). Trust).

\section{METHODOLOGY}

Paradigm underline this study is path paradigm, with statistic analysis technique so called Structural Equation Modeling (SEM). Said to Hair et al (2002:67) by using SEM likely be done an analysis on correlation series simultaneously then resulting in statistically efficiency.

Population of this study are employees of Surabaya fire fighters who had appointed as Civil Servant (PNS). Total of 200 employees. For sampling use proportional sampling. This technique likely to get sample on each Surabaya fire fighters and done based on allocation method proportionally. (Nazir 199:309)

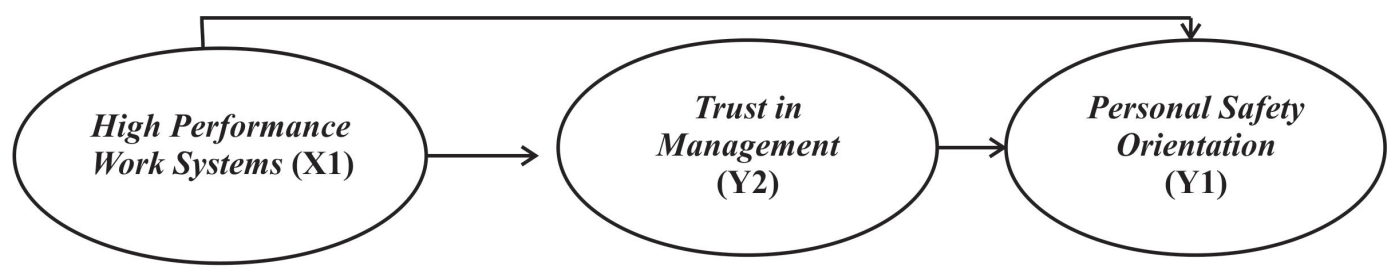

Figure 1. Conceptual Framework 
RESULTS AND DISCUSSION

Here are Regression Weight and Standardized Regression Weight structural equation models

Tabel 1.

Uji Kausalitas Regression Weight

\begin{tabular}{|c|c|c|c|c|c|c|c|}
\hline \multicolumn{3}{|c|}{ Causality Relations } & $\begin{array}{c}\text { Std. } \\
\text { Estimate }\end{array}$ & S.E. & C.R. & $\begin{array}{c}P \text { - } \\
\text { value }\end{array}$ & Information \\
\hline $\begin{array}{c}\text { High } \\
\text { Performance } \\
\text { Work System } \\
\left(\mathrm{X}_{1}\right)\end{array}$ & $\rightarrow$ & $\begin{array}{c}\text { Personal } \\
\text { Safety } \\
\text { Orientation } \\
\text { (Y) }\end{array}$ & 0,043 & 0,067 & 0,523 & 0,601 & InSignificant \\
\hline $\begin{array}{c}\text { High } \\
\text { Performance } \\
\text { Work System } \\
\left(\mathrm{X}_{1}\right) \\
\end{array}$ & $\rightarrow$ & $\begin{array}{c}\text { Trust In } \\
\text { Management } \\
\left(\mathrm{Z}_{2}\right)\end{array}$ & 0,238 & 0,075 & 2,958 & 0,003 & Significant \\
\hline $\begin{array}{c}\text { Trust In } \\
\text { Management } \\
\left(\mathrm{Z}_{2}\right)\end{array}$ & $\rightarrow$ & $\begin{array}{c}\text { Personal } \\
\text { Safety } \\
\text { Orientation } \\
\text { (Y) }\end{array}$ & 0,215 & 0,086 & 2,174 & 0,030 & Significant \\
\hline
\end{tabular}

Source: data processed

Based on table 1 above, it can be explained that the result of regression weight test, it can be explained that the result of regression weight test has CR value greater than 1,96 and p-value less than $5 \%$, so $\mathrm{H}_{1}, \mathrm{H}_{2}$, is acceptable and $\mathrm{H} 3$ is unacceptable, unless high performance work system variable to personal safety orientation shows insignificant results with CR value of 0.523 (smaller than 1.96) and the level of significance ( $p$-value) of 0.601 (greater than 5\%).

\section{CONCLUSION}

The result of the study showed that High Performance Work System influence insignificant on Personal Safety Orientation, High Performance Work System have significant influence on Trust in Management, Trust in Management have significant Personal Safety Orientation.

\section{References}

Ahmad, S., dan Schroeder, R.G. 2003. “The Impact of Human Resource Management Practices on Operational Performance: Recognizing Country and Industry Differences."Journal of Operations Management, 21 (1), $19-43$.

Arthur, J. B. 1992. "The link between business strategy and industrial relations systems in American steel minimills." Industrial and Labor Relations Review, 45, 488-506.

Arthur, J. B. 1994. "Effects of human resource systems on manufacturing performance and turnover." Academy of Management Journal, 37, 670-687.

Azwar, S. 1999. Penyusunan Skala Psikologi. Yogyakarta: Pustaka Pelajar.

Bae, J., dan Lawler, J.J. 2000. “Organizational and HRM-Strategies in Korea: Impact on Firm Performance in an Emerging Economy.” Academy of Management Journal, 42 (3), 502-517.

Barling, J., Loughlin, C., dan Kelloway, E. K. 2002. “Development and test of a model linking transformational leadership and occupational safety."Journal of Applied Psychology, 87, 488-496.

Barling, J., Kelloway, E. K., dan Iverson, R. D. 2003. “High-quality jobs, job satisfaction and occupational safety."Journal of Applied Psychology, 88, 276-283.

Damanpour, F. (1991). Organizational innovation: A meta-analysis of effects of determinants and moderators. Academy of management journal, 34(3), 555-590.

Griffin, M. A., \& Neal, A. (2000). Perceptions of safety at work: a framework for linking safety climate to safety performance, knowledge, and motivation. Journal of occupational health psychology, 5(3), 347-358.

Kerlinger, Fred N. (2004). Asas-asas Penelitian Behavioral. Yogyakarta: Universitas Gadjahmada. 
McAllister, D.J. (1995). Affect- and Cognition-Based Trust as Foundations for Interpersonal Cooperation in Organizations. Academy of Management Journal, 38: 24-59.

McCollum, S. (2009). Managing Resolution Conflict. New York: InfobasePublishing.

Mowday, R. T., Porter, L. W., \& Steers, R. M. (1982). Employee Organization Linkage: The Psychology of Commitment, Absenteeism and Reparation.New York:Academic Press.

Neal, A. \& Griffin, M. A. (2004). Safetyclimate and safety at work. Dalam thepsychology of workplace safety. In J. Barling\& R.F. Michael (Eds.). Washington: American Psychological Association.

Robbins, S.P.(2004). Organization Theory: Structure, Design and Applications,Terjemah JusufUdaya, Teori Organisasi: Struktur, Desain danAplikasi, Jakarta, Arcan.

Santoso, G. (2004). Manajemen keselamatan dan kesehatan kerja. Prestasi Pustaka Publisher.

Schneider, B., Wheeler, J. K., \& Cox, J. F. (1992). A passion for service: Using content analysis to explicate service climate themes. Journal of applied psychology, 77(5), 705. 